\title{
Policy Effectiveness of Loan for Delaying Timber Harvesting for Smallholder Private Forest in Indonesia
}

\author{
Bramasto Nugroho $^{1 *}$, Sudarsono Soedomo ${ }^{1}$, Ahmad Dermawan ${ }^{2}$ \\ ${ }^{1}$ Department of Forest Management, Bogor Agricultural University, Jalan Raya Dramaga, \\ Kampus IPB Dramaga, Bogor, Indonesia 16680 \\ ${ }^{2}$ Center for International Forestry Research, Jalan CIFOR, Situ Gede, Bogor, Indonesia 16115
}

Received May 23, 2017/Accepted July 21, 2017

\begin{abstract}
This study aimed to analyze policy effectiveness of loan for delaying timber harvesting for smallholder private forest business (Pinjaman Tunda Tebang Hutan Rakyat; hereinafter will be referred as PTT-HR). The analysis will be used to provide recommendations for improving PTT-HR scheme included scaling out and scaling up of the scheme for improving economic benefits and supporting smallholder private forest business as well as for strengthening farmer's welfare. Field survey was conducted in October-November 2013 in two districts in Central of Java, Indonesia namely Blora and Wonosobo District as recipient of PTT-HR from Public Service Agency for Forest Development Financing Center (BLU Center of P2H) Ministry of Forestry, Republic of Indonesia. The results showed that PTT-HR policy has implemented effectively based on evaluation parameter derived from the objectives of policy namely the age of the stands for loan collateral, the capabilities for improving farmer's welfare, utilization of loan, perception of the farmers regarding to the ease of the process and purpose of loan utilization, and the capability of loan repayment. However, this research has not been answered the aspect of PTT-HR policy implementation efficiency.
\end{abstract}

Keywords:effectiveness, policy, loan for delaying timber harvesting, smallholder private forest, welfare

*Correspondence author, email: bramasto2001@yahoo.co.id;ph.+62-251-8621244

\section{Introduction}

One of the problems faced by smallholder private forest (SPF) is their low financial capacities to fulfill their urgent needs of money in large amount such as children marriage ceremony expenses, health cares, children's school fees and house construction or renovation. In such situations farmers are forced to cut their immature trees. The phenomenon is known as "harvesting for urgent needs (tebang butuh)" (Hardjanto 2001; Prihadi 2010; Nugroho \& Tiryana 2013). In that condition bargaining position of farmers becomes weaker, so farmers will lose their opportunity to get optimum selling price. If any available micro credit institutions that can solve such urgent needs, farmer will have flexibilities for deciding the optimal age of trees will be harvested. Those flexibilities will increase economic benefits of the trees (Tee etal.2010).

In 2012, Ministry of Forestry, Republic of Indonesia (MoF RI) through Public Service Agency for Forest Development Financing Center (BLU Center of P2H) has already launched a program called Revolving Fund Facilitation (RFF) for supporting forest and land rehabilitations (FLR) that regulated in MoF RI Decree Number P.36/2012 about loan distribution and repayment mechanisms of RFF for FLR activities. To operate that regulation, Head of Center $\mathrm{P} 2 \mathrm{H}$ issued A Decree No. 01/2012 about loan application guideline for SPF development without intermediary institution. Based on that decree one of the loan schemes available is loan for delaying timber harvesting for smallholder private forest business (Pinjaman Tunda Tebang Hutan Rakyat; here in will be referred as PTT-HR).

Based on MoF RI Decree No 36/2012 there are some principles in RFF granting namely for empowering of people economies, poverty alleviations, expansion of employment opportunities, increasing forest productivities and environmental quality improvements regarding to FLR, with affordable terms and prudential principles. This matter is intended to strengthen business capital (investment) for FLR activities. Considering those principles and intentions, it seems that PTT-HR as one variant scheme of RFF can be categorized as micro and small credit (MSC). Basically the presence of MSC is mainly aimed to alleviate poverty with intension to provide farmer an opportunity for developing their livelihoods by them self to improve their income (Rauf \& Mahmood 2009; Ondoro \& Omena 2012; Qureshi et al. 2012). MSC facilitation characteristics are targeted to poor people, farmers and micro-small businessmen, the targets have not bankable assets and subsidized interest rate (Ejigu 
2009; Singh 2012; Bichanga \& Aseyo 2013). Access availability of MSC institutions is indeed highly required by poor farmers in the rural (Yunus 1981; Khandker et al. 1995), because formal bank institution is difficult to lend their money to farmers who havenot bankable assets and to small agricultural based businesses (Usman et al. 2004; Wijono 2005; Onoja \& Agumagu 2009).

Not all of MSC programs are successful. Rauf \& Mahmood (2009) reported that although in general the MSC programs in Pakistan show growth and significant progress but require a high management cost of MSC. Research results of Bichanga \& Aseyo (2013) shows that most of the MSC recipients in Trans Nzoia County, Kenya failed to repay their loan caused by weak of supervision, lack of training program for management and utilization of loan, loan utilization didnot match with the goal of lending, borrowers didnot have enough assets for repaying the loan as well as household income has been drained to finance daily living. A similar failure occurred in Indonesia on granting business credit program for smallholder private forest (KUHR) and small business credit for watersheds (KUK-DAS) (Nugroho 2011). During 1997-2000 KUHR funds distributed for amount of IDR107.58 billion, but until May 2010 there are arrears of principal loan amounting to IDR 105.82 billion and interest amounting to IDR65.15 billion. While the distribution of KUK-DAS amounting to IDR41.91 billion can only repaid amounting to IDR21.78 billion (52\% from the loan) or resulted bad debts amounting to IDR20.12 billion (48\% from the loan).

However, research of MSC program in Andra Pradesh, India concluded that although MSC couldnot resulting substantial net economic incomes for the farmers, but the program succeed to improve social capital, empower and engage women, create social safety net, and improve the collective actions for fighting loan-shark (Ajit \& Rajeev 2012). According to Yunus (2007) empowerment and involvement of women in the management of MSC will increase the level of certainty in loan repayment, because generally women are more discipline in their use of the loan.

Normatively PTT-HR can be hoped to increase SPF surplus. Without support from PTT-HR, the farmers are forced to sell their trees under the optimum harvesting cycle, when they have urgent needs. PTT-HR has a role to avoid those compulsions, so SPF able to choose optimum harvesting time that gives more benefits. In the delaying time of harvesting the stands (trees) have opportunity to grow significantly and log prices will raise better.

Considering the research results of MSC program implementation from several countries explained above, the question in this research is "It is true that PTT-HR can increase SPF financial benefit, improve farmer's welfare and support SPF business"? For that reasons, this study will focuses on effectiveness of PTT-HR by taking sample cases in Wonosobo and Blora (Province of Central Java, Indonesia) with the aim to draw up a recommendation for improving and find out the methods for scaling out and scaling up of PTTHR scheme to enhance economic benefits of SPF business, improve the welfare of farmers, and support SPF business.

\section{Methods}

This study uses a descriptive-evaluative research approach that is a study intended to explain in depth the result of policy evaluation (Elliot 2005; Irawan 2007). Policy evaluation is conducted to determine whether the implementation of such a policy was in accordance with the objective (refer to effectiveness) and is there guarantee that the funds for the implementation is not wasted (refer to efficiency) (Dye 2002; Dunn 2003; Tron 2009). In this study the focus of policy evaluation is limited to know effectiveness.

The main problem in granting loans is the existence of asymmetric information between the lender and the borrower (Nugroho 2010). Theoretically, asymmetric information between parties can potentially induce moral hazard in ex post situation. The form of moral hazard for the lender can be mismatch between the money mentioned in the credit agreement and the money received by borrowers, while from the borrower's side may be a non-conformity of loan repayment either about the amount and time of repayment of the loan.

Policy that evaluated is direct incentives policy for providing access to farmer of SPF that was initiated by MoF RI (MoF RI Decree Number 36/2012 and Head of Center of P2H Decree Number 01/2012) with the aim to improve the welfare of farmers and to support business of SPFs. The method used is quantitative approach using structured questioner. The questionaire is developed to get information about (a) design of policies and implementation of PTT-HR loans, (b) the participation of community, (c) system to anticipate failure of repayment, (d) performance of PTT-HR (access, loan repayment prospect, and appropriateness to resolve harvesting for urgent needs), and (e) impact of PTTHR on farmers welfare. All information will be used to improve PTT-HR schemes regarding to the replication in other places (scale out) and the enhancement of the scale (scaled up) of PTT-HR.

There is several information are needed for assessing the impact of PTT-HR that gives benefit for the farmers. Firstly, a pattern of tree growth $(\mathrm{V}(t))$ i.e. relation between tree age and its volume. This information is needed to estimate incremental volume of the trees during delaying time of timber harvesting. Secondly, information about trends of wood price per unit volume $p(t)$. Thirdly, information about interest rate of PTT-HR.

In accordance with the provisions of central $\mathrm{P} 2 \mathrm{H}$ the amount of the loan is given based on the number of collateral trees. In this study, the calculation of additional benefits from PTT-HR will be based on per collateral tree. At time $(t 0)$ it assumed that farmers sell the tree at price $p(t 0)$ per tree. Revenue gained by the farmers for selling one tree at time $t 0$ is $R s(t 0)=p(t 0)$. When the farmer's needs can be covered by PTT-HR the revenue of farmer at $(t 0)$ was equal to the credit acquired that is $80 \%$ of selling price, say $\mathrm{R} k(t 0)$ per tree. Say that harvesting and selling of one tree will be at time $t \mathrm{n}(>t 0)$ and farmers will earn a revenue of $\mathrm{R} s(t \mathrm{n})=p(t \mathrm{n})$ per tree. But, the farmers must repay the principal $\mathrm{R} k(t 0)$ plus interest (that calculated using simple interest method) as 
much as $\mathrm{R} k(t 0)(\mathrm{tn}-\mathrm{t} 0)(\delta)$, so the net revenue received by farmers on $(t \mathrm{n})$ is $\mathrm{R} n(t \mathrm{n})=\mathrm{R} s(\mathrm{t} 0)-\mathrm{R} k(t 0)-\mathrm{R} k(t 0)(t \mathrm{n}-$ $t 0)(\delta)$. The farmer have also to pay annual maintenance cost of the tree, say $\mathrm{c}(\mathrm{m})$ per tree, so total maintenance costs during lending period is $c(t)=\sum_{(t 0-1)}^{(t n-1)} c(m)$. Therefore, the present value of surpluses gained by the farmers from PTTHR program that assessed on $(t 0)$ is as shown in Equation [1]:

$$
S=R n(t n)(1+\delta)^{-(t n-t 0)}-c(t)-R s(t 0)
$$

In which $\delta$ is discount rate (\%).

Farmers will decide to join PTT-HR program to delay harvesting if $\mathrm{S}>0$ and instead not to follow PTT-HR program if $\mathrm{S}<0$. The fact that there are farmers willing to join PTT-HR program, then for a while it is assumed that farmers get surplus from the PTT-HR.

This research was conducted on two sites which have PTT-HR program from Center of $\mathrm{P} 2 \mathrm{H}$. The first site was located in Wonosobo (Central Java, Indonesia) which represents a region with plant composition having a cutting cycle of less than eight years and a second site located in Blora (Central Java, Indonesia) representing a region with plant composition having a cutting cycle of more than eight years. Field research conducted between OctoberNovember 2013.

The surveyed population is a farmer groups in Wonosobo and Blora that received PTT-HR from Center of P2H. In Wonosobo there is one group of farmer with total of 37 members who become borrower of PTT-HR program. While in Blora there are eight groups of farmer with a total of 137 borrowers. The sample size will be calculated by Slovin's formula as follow (Ridwan 2009):

$\mathrm{n}=\frac{N}{\left(\mathrm{~N} \cdot \mathrm{d}^{2}+1\right)}$
Note: $\mathrm{N}=$ total of population, $\mathrm{n}=$ sample size, $\mathrm{d}=$ sampling error (in this research is $10 \%$ )

Based on the Slovin's formula the sample size in Wonosobo consist of 27 borrowers (from 37 borrowers) and Blora was 58 borrowers (from 137 borrowers). So the total samples in the two studied districts are 85 respondents.

\section{Results and Discussion}

Policy design of PTT-HR and the implementation P T T $\mathrm{HR}$ is a type of loan services provided by Center of $\mathrm{P} 2 \mathrm{H}$ to prevent the trees from being felled before reaching the optimal age or diameter. The borrower is obliged to return the principal and its interest after a certain period of time (lending period). PTT-HR is one of four loan schemes provided by Center of $\mathrm{P} 2 \mathrm{H}$ to support SPF management in Indonesia namely loans for (1) SPF development and/or enrichment, (2) SPF maintenance, (3) agroforestry development, and (4) delaying timber harvesting (PTT-HR) itself.

The term of conditions for the PTT-HR include (Perkapus P2H No. 01/2012): (1) trees that can be used as collateral are the ones that have market value but still too young to be cut, (2) loan is given to the owner of the SPF who need a quick cash money while the trees is too young to be cut, (3) lending period is 5 years for long rotation species that needs more than 8 years to harvest and 3 years for short rotation species that needs less than 8 years to harvest, (4) loan delivery plan that is proposed in loan application for each parcel of land is made gradually according to diameter class or percentage of tree used as collateral, (5) the maximum limit of PTT-HR for each farmer group/cooperative is equivalent to 80.000 trees multiplied by standard cost of a tree, which is IDR20,000 per tree (Decree of the Head of Center of P2H Number

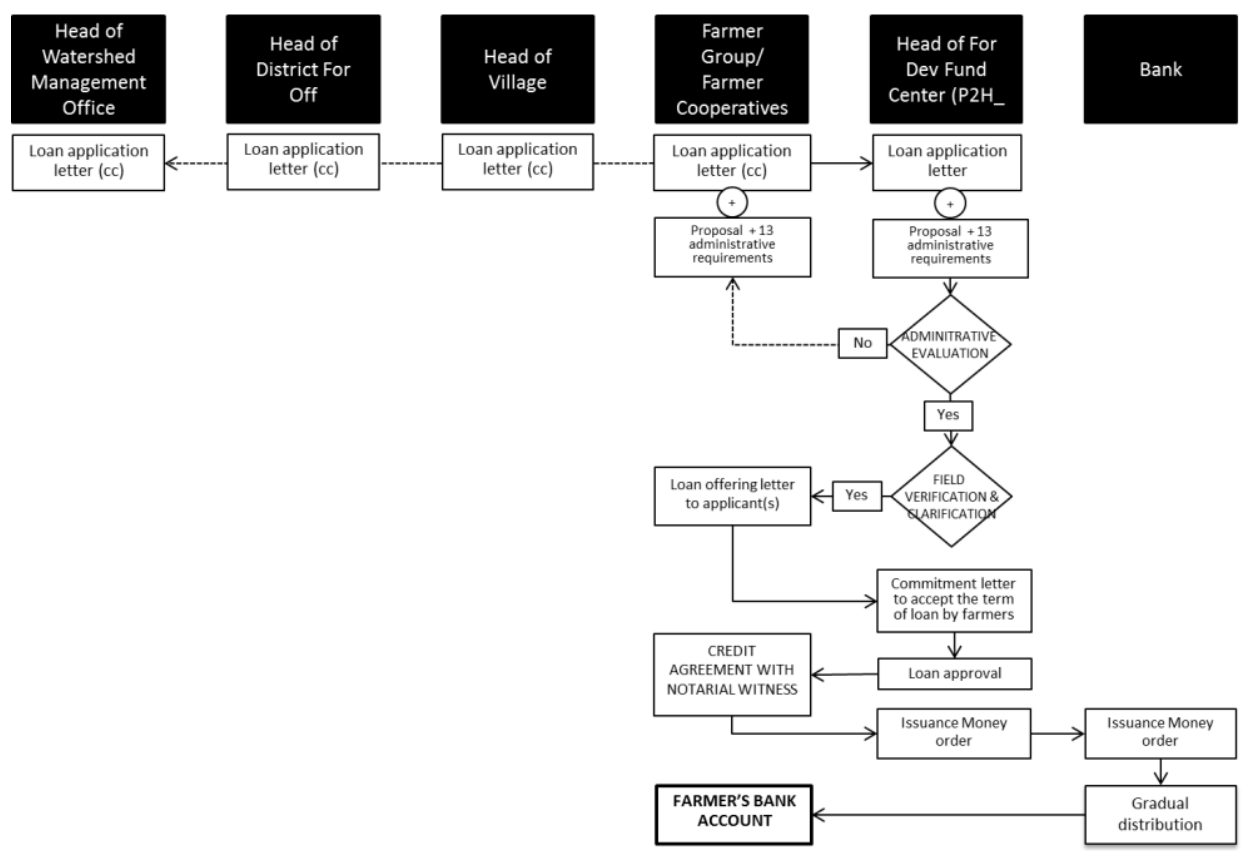

Figure 1 The application mechanism of PTT-HR. 
SK.16/P2H-1/2012), and (6) PTT-HR given is at most $80 \%$ of local market price. The application mechanism of PTT-HR program presented in Figure 1.

Based on the regulation basically the PTT-HR scheme is really about providing farmers with credit and use trees as a collateral for certain period. After lending period is exceeded and the loan is repaid, the rights to the tree are fully returned to the borrower. This indicates that only the farmers who have tree will eligible to obtain the loans. This is understandable because the purpose of PPT-HR is to prevent tree owners from selling their immature trees.

As of September 2013 the amount of loans that have been disbursed for four schemes of RFF was IDR24.73 billion for the 1,455 borrowers who joined in the 64 farmer groups. While loans disbursed to the PTT-HR scheme in the study area were IDR3,332,288,000 in which IDR201,312,000 to Wonosobo District and IDR3,130,876,000 to Blora District.

The information about PTT-HR program is given by Center of $\mathrm{P} 2 \mathrm{H}$ in conjunction with local government Forestry Office to leader of farmer group. Then the information is announced to the members of the group by leader of farmer group. The application of PTT-HR is submitted by the farmers group to Center of $\mathrm{P} 2 \mathrm{H}$ office. Farmers who are interested in this program has to prepare some requirements like ID card, tally sheet of farmer's tree and letter of land ownership. Those all process is carried out by farmer group administrators without any supporting funds from Center of $\mathrm{P} 2 \mathrm{H}$.

After all requirements has been collected then the farmers group prepare proposal. It was sent directly to Center of $\mathrm{P} 2 \mathrm{H}$. It took about 3-6 month waiting time for receive reply from Center of $\mathrm{P} 2 \mathrm{H}$, because of many incoming proposals to Center of $\mathrm{P} 2 \mathrm{H}$ and limited of human resources of Center $\mathrm{P} 2 \mathrm{H}$. The Center of $\mathrm{P} 2 \mathrm{H}$ evaluated all of documents from each individual farmer to decide potential borrowers (desk evaluation). The farmers who are considered to be potential borrowers will be verified in their origin area for field checking of the loan proposal and the conformity between registered tree in the tally sheet and its reality in the field randomly (field evaluation).

The next step after field checking is signing the credit agreement with notarial witness. This process took about 1-2 weeks. Credit agreement is signed under notarial witness and should be attended by married couple (if candidate has married) and ensured that whether the individual actually wants to get PTT-HR and did not under pressure by other parties. The loan is disbursed directly from the Center of $\mathrm{P} 2 \mathrm{H}$ to each farmer who got loans with the assistance of BRI Bank to transfer of its funds.

The community participation The farmer roles in PTT-HR application is mainly in preparing personal requirements such as ID card and letter of land ownerships. The community's response to this program is very positive, because: (1) the community feels that this program can potentially increasing the household income; (2) this program is seen as one source of capital to develop other businesses and (3) PTT-HR require small interest rates than other lending institutions (banks or credit unions). In the study locations, the bank required $15 \%-20 \%$ per annum interest rate, credit union applied $1.5 \%$ per month (or $18 \%$ per annum), but PTT-HR required only $5.75 \%$ per annum as much as Bank of Indonesia rate (BI rate).

Standing stock (trees) as collateral is seen as a new breakthrough and fits perfectly with the character of the community in Wonosobo and Blora. Those relevancies and appropriateness become important factors in supporting effectiveness of the policies (Varone et al. 2006). For the community, tree is an asset that has been used as a savings account in which can be used to fulfill urgent needs with a large amount of money. People realize that older tree have higher price, but sometimes they are forced to harvest the trees prematurely due to urgent circumstances. With the PTT-HR program, farmers are possible to maintain the trees until reaching the optimal economic value, beside get additional benefits from delaying timber harvesting.

Anticipating the delay and/or failure of repayment The survey result on Table 1 shows the mechanism to anticipate repayment failure, the efforts to make loan repayment on time, and possible forms of plant failure at the study site.

Selling the livestock and agriculture products is the main option for many borrowers at Wonosobo and Blora to overcome repayment failure. This option was chosen by 26 respondents (96\%) at Wonosobo. They have confidence that selling the livestock and agriculture products would be enough to fulfill their loan repayment. While in Blora shows the different ways, in which only $44.8 \%$ of respondents who choose to repay the loan from livestock and agriculture products, and $46.6 \%$ respondents chose to reschedule the repayment.

Most of Wonosobo peoples had the confidence to fulfill the loan repayment from the livestock and agriculture products instead of selling the collateral trees. Collateral trees in Wonosobo are sengon (Paraserianthes falcataria) that had only less than eight years harvesting cycle and had lower economic value than teak (Tectona grandis) that generally are used as collateral by farmers in Blora. It is imply to the amount of loan that received by farmers in Wonosobo who got loan less than IDR20 million lower than those in Blora that mostly received more than IDR20 million.

Most of borrowers in Blora are more prefer to extend the repayment time in order to get higher economic value from the collateral trees. Besides the business funded by PTT-HR also become more established. However, most borrowers in Blora also have confident that they could repay the loan from selling their livestock and/or agricultural products.

The potential failure that might occur in Wonosobo is tree pests and diseases. Most of borrowers have the obstacles related to "karat furu" and worm that attack their trees. From the interviews, 27 respondents $(100 \%)$ in Wonosobo stated that pests and diseases are the main problem faced by farmer in maintaining collateral trees. Even currently there are collateral trees that have been felled because affected by pests and diseases, they had the fear that the trees would be dead and could not be sold. Whereas in Blora, 32 respondents $(55.2 \%)$ stated that the potential failures that may occur in 
Table 1 Questionnaire result related to the loan payment and the possible failure form

\begin{tabular}{|c|c|c|c|c|c|c|}
\hline \multirow{2}{*}{ Aspect } & \multicolumn{2}{|c|}{ Wonosobo } & \multicolumn{2}{|c|}{ Blora } & \multicolumn{2}{|c|}{ Total } \\
\hline & $\mathrm{n}$ & $\%$ & $\mathrm{n}$ & $\%$ & $\mathrm{n}$ & $\%$ \\
\hline Selling livestock and agriculture products & 26 & $96.3 \%$ & 26 & $44.8 \%$ & 52 & $61.2 \%$ \\
\hline Rescheduling repayment & 1 & $3.7 \%$ & 27 & $46.6 \%$ & 28 & $32.9 \%$ \\
\hline Sell the family assets & - & - & 1 & $1.7 \%$ & 1 & $1.2 \%$ \\
\hline Selling assets and rescheduling repayment & - & - & 1 & $1.7 \%$ & 1 & $1.2 \%$ \\
\hline \multicolumn{7}{|c|}{ Borrowing money from other institutions and rescheduling } \\
\hline repayment & - & - & 1 & $1.7 \%$ & 1 & $1.2 \%$ \\
\hline \multicolumn{7}{|l|}{ Tree failure possibility causes: } \\
\hline Pests and Diseases & 27 & $100 \%$ & 12 & $20.7 \%$ & 39 & $45.9 \%$ \\
\hline Natural disasters & - & - & 32 & $55.2 \%$ & 32 & $37.6 \%$ \\
\hline Fire & - & - & 7 & $12.1 \%$ & 7 & $8.2 \%$ \\
\hline Thievery & - & - & 7 & $12.1 \%$ & 7 & $8.2 \%$ \\
\hline
\end{tabular}

maintaining collateral trees is natural disasters such as winds that can break the tree trunks. The other factors are pests and diseases that stated by 12 respondents $(20.7 \%)$, thievery (12.7\%), and forest fires (12.7\%).

Performance of loan for delaying timber harvesting (PTT-HR) Performance of PTT-HR is assessed based on the ease of the loan acquiring process, required time from the loan application step up to the loan disbursement, utilization of the funds by the borrower, and funds disbursement phases to borrowers. Table 2 shows the result of interviews related to the PTT-HR performance from 27 respondents in Wonosobo and 58 respondents in Blora.

PTT-HR application process perceived easily by the majority of borrowers $(76.5 \%)$, mainly due to the ease of loan requirements such as ID card and letter of land ownerships which is later on to be processed by the farmers group administrators. Farmers in Wonosobo have more advantage in this process because their land already certificated, whereas in Blora the farmers initially had an obstacle in the land ownership document.

On the contrary, for the management of farmer groups who take care of all member administrations up to the proposal-making stage, the PTT-HR lending process is difficult. Respondents who stated difficult (17.25\%) and very difficult $(6.9 \%)$ in Blora are mainly farmer group administrators. It is caused by the farmer group administrators has to compile all of personal requirements from the members, prepare proposal of the loan and submit the proposal to Center of $\mathrm{P} 2 \mathrm{H}$ without any support of money from whoever. They also encountered problem regarding to the additional requirements from Center of $\mathrm{P} 2 \mathrm{H}$ during the proposal making step, such as letter of land ownership that previously allow only using land tax notification letter (SPPT), but then there was a change to include letter of heritance of the land or grant letters if trees growing in a land that is not in the name of the borrower. The administrators of the farmer group felt that the system is burdensome because of the lack of operational costs, more over they also have to submit the proposal to Center of $\mathrm{P} 2 \mathrm{H}$ office in Jakarta using money from the organization.

Time required from the submission process until signing the loan agreement complained also by most all of borrowers. It takes up to 4 months in Wonosobo. Meanwhile in Blora takes more than 5 months caused by Mustika Jati Farmer Group Association which is consists of 8 farmer groups who spread across 8 villages want to submit the loan proposal collectively, so that the farmers groups who already completed all the document requirements have to wait the other farmer groups who have not been completed it.

Most of the borrowers $(96.5 \%)$ said that the money they have received is already matched with the proposal. But, there were complaints that the price of collateral tree estimated by Center of $\mathrm{P} 2 \mathrm{H}$ were lower than those estimated by borrowers (expressed by $98.8 \%$ of respondents). Probably the low estimation of price caused by prudential principles that applied by Center of $\mathrm{P} 2 \mathrm{H}$.

Most respondents in Wonosobo (63.0\%) and Blora $(84.5 \%)$ used PTT-HR funds for business capital such as livestock business, farming, buying truck, trading, and agroforest cultivating. Other small parts (22.4\%) use it to buy motorcycle, purchase land, renovate houses, children's school fees, and even for political needs namely village head election campaign. In the long term the use of PTT-HR funds for business capital is expected to alleviate poverty, develop self-employed farmers' businesses that can generate revenues, empower the people's economy, expand employment opportunities, and become a source of income for the strengthening of loan repayments.

Principally lending period that specified by $\mathrm{P} 2 \mathrm{H}$ Center both in Wonosobo and Blora had been appropriate i.e three years for sengon and five years for teak. But there are other 
Table 2 Performance of PTT-HR

\begin{tabular}{|c|c|c|c|c|c|c|}
\hline \multirow{2}{*}{ Aspect } & \multicolumn{2}{|c|}{ Wonosobo } & \multicolumn{2}{|c|}{ Blora } & \multicolumn{2}{|c|}{ Total } \\
\hline & $\mathrm{n}$ & $\%$ & $\mathrm{n}$ & $\%$ & $\mathrm{n}$ & $\%$ \\
\hline \multicolumn{7}{|l|}{ Loan acquiring process: } \\
\hline Very easy & 2 & $7.4 \%$ & - & - & 2 & $2.4 \%$ \\
\hline Easy & 24 & $88.9 \%$ & 41 & $70.7 \%$ & 65 & $76.5 \%$ \\
\hline Moderate & 1 & $3.7 \%$ & 3 & $5.2 \%$ & 4 & $4.7 \%$ \\
\hline Difficult & - & - & 10 & $17.2 \%$ & 10 & $11.8 \%$ \\
\hline Very difficult & - & - & 4 & $6.9 \%$ & 4 & $4.7 \%$ \\
\hline \multicolumn{7}{|l|}{$\begin{array}{l}\text { Required time from the submission until loan } \\
\text { agreement: }\end{array}$} \\
\hline 120 days & 27 & $100.0 \%$ & - & - & 27 & $31.8 \%$ \\
\hline 150 days & - & - & 11 & $19.0 \%$ & 11 & $12.9 \%$ \\
\hline 180 days & - & - & 29 & $50.0 \%$ & 29 & $34.1 \%$ \\
\hline 365 days & - & - & 18 & $31.0 \%$ & 18 & $21.2 \%$ \\
\hline \multicolumn{7}{|c|}{$\begin{array}{l}\text { The institutions/person who helped the submission } \\
\text { of the loan: }\end{array}$} \\
\hline Farmers group & 27 & $100 \%$ & 58 & $100 \%$ & 85 & $100 \%$ \\
\hline \multicolumn{7}{|c|}{ The appropriateness of the loan amount received: } \\
\hline Appropriate & 26 & $96.3 \%$ & 56 & $96.6 \%$ & 82 & $96.5 \%$ \\
\hline Not appropriate & 1 & $3.7 \%$ & 2 & $3.4 \%$ & 3 & $3.5 \%$ \\
\hline \multicolumn{7}{|l|}{ Utilization of PTT -HR fund: } \\
\hline Educational needs & - & - & 2 & $3.4 \%$ & 2 & $2.4 \%$ \\
\hline Daily needs & 3 & $11.1 \%$ & - & - & 3 & $3.5 \%$ \\
\hline Vehicle needs & 1 & $3.7 \%$ & 3 & $5.2 \%$ & 4 & $4.7 \%$ \\
\hline $\begin{array}{l}\text { Business capital ( livestock, truck, trading, } \\
\text { farm/garden, sugar) }\end{array}$ & 17 & $63.0 \%$ & 49 & $84.5 \%$ & 66 & $77.6 \%$ \\
\hline Political needs (head of village campaign) & - & - & 2 & $3.4 \%$ & 2 & $2.4 \%$ \\
\hline Repayment of a loan & - & - & 1 & $1.7 \%$ & 1 & $1.2 \%$ \\
\hline Savings & 1 & $3.7 \%$ & - & - & 1 & $1.2 \%$ \\
\hline Buying the land & 1 & $3.7 \%$ & - & - & 1 & $1.2 \%$ \\
\hline House renovation & 4 & $14.8 \%$ & 1 & $1.7 \%$ & 5 & $5.9 \%$ \\
\hline \multicolumn{7}{|l|}{ Conformity with the problems encountered: } \\
\hline Could solve the problem & 16 & $59.3 \%$ & 54 & $93.1 \%$ & 70 & $82.4 \%$ \\
\hline Does not resolve problem & 11 & $40.7 \%$ & 4 & $6.9 \%$ & 15 & $17.6 \%$ \\
\hline \multicolumn{7}{|l|}{ Lending period: } \\
\hline 1 year & 1 & $3.7 \%$ & - & - & 1 & $1.2 \%$ \\
\hline 3 years & 15 & $55.6 \%$ & - & - & 15 & $17.6 \%$ \\
\hline 5 years & 11 & $40.7 \%$ & 45 & $77.6 \%$ & 56 & $65.9 \%$ \\
\hline 8 years & - & - & 4 & $6.9 \%$ & 4 & $4.7 \%$ \\
\hline 10 years & - & - & 9 & $15.5 \%$ & 9 & $10.6 \%$ \\
\hline \multicolumn{7}{|l|}{ Fund disbursement phases: } \\
\hline 1 time & 27 & $100.0 \%$ & 55 & $94.8 \%$ & 82 & $96.5 \%$ \\
\hline 2 times & - & - & 1 & $1.7 \%$ & 1 & $1.2 \%$ \\
\hline 3 times & - & - & 2 & $3.4 \%$ & 2 & $2.4 \%$ \\
\hline
\end{tabular}

respondents propose to lengthen the lending period up to five years for sengon and $8-10$ years for teak. The addition of lending period would make their business (investment) will be more established besides their collateral trees would be older and bigger as well as more expensive.

The other thing that complained by $96.5 \%$ of respondents were phases within loan funds disbursement. The rules applied by BLU is for a loan below IDR10 million will be disbursed within one phase, IDR10-IDR20 million within two phases, and > IDR20 million within three phases. This gradual disbursement mechanism can't be utilized funds optimally from respondent point of view, especially if it is to be used for business capital.

\section{PTT-HR impacts to the farmer's welfare}

\section{Teak as collateral}

The teak trees which can be used as collateral are very diverse, there are farmers who choose large diameter 
trees in order to received large loan amount, but there are also farmers who choose the small diameter trees. In this study the size of the tree used as the basis for calculating the incremental of welfare or profit is the size of the tree most often used as loan collateral that is $10-13 \mathrm{~cm}$ diameter with the age of about 10 years and with an estimated price of IDR76,000 per tree. Based on field data, within a period of five years, the tree will be sized from $16-19 \mathrm{~cm}$ with a price of IDR 185,000 up to IDR260,000 per tree depend on the quality. The present value of benefit received by farmers $(S)$ in some probability of prices per tree at the end of lending period and at some interest rates can be described in Table 3 using calculation basis as follow:

1 Under the terms of loans, the maximum amount of loans that would be obtained by borrowers is $80 \%$ from market price of the collateral trees (IDR60,800 per tree);

2 Principal of loan and interest is paid at the end of lending period;

3 Interest (5.75\% per annum) calculations using a simple interest method as regulated by Center of $\mathrm{P} 2 \mathrm{H}$;

4 Annual maintenance costs is IDR 15,000 per tree or IDR7,500,000 per ha (with 500 trees ha' ${ }^{-1}$ ).

Table 3 .

Table 3 explains that at all possible prices at the end of lending period (from IDR 185,000 up to IDR260,000 per tree) with interest rate up to $7.5 \%$, the present value of additional benefits received by farmers who borrow PTTHR $(S)$ are positive $(S>0)$. Thus, by borrowing the money in order to fulfill their urgent needs from the Center of $\mathrm{P} 2 \mathrm{H}$ will be profitable than selling the teak. In other words, the additional value during lending period is greater than the value of the principal loan and its interest.

2 Sengon as collateral

In the case of sengon as collateral, commonly the farmers collateralized their trees in aged of 5-15 years with three years lending period. The average price of sengon per tree is IDR25,000 at age 5 years, IDR40,000-IDR60,000 per tree at age 10 years, and IDR80,000-IDR200,000 per tree at age 15 years. In this case the size of the tree most often used as loan collateral is tree at age five years and tree at age 10 years.

The present value of benefit received by farmers (S) in some probability of prices per tree at the end of lending period and at some interest rates can be described in Table 4 for the case of collateral tree at age five years and Table 5 for the collateral tree at age 10 years using calculation basis as follow:

1 Under the terms of loans, the maximum amount of loans that would be obtained by borrowers is $80 \%$ from market price of the collateral trees (IDR20,000 per tree for the collateral tree at age five years and IDR 40,000 per tree for the collateral tree at age 10 years);

2 Principal loan and its interest is paid at the end of lending period;

3 Interest (5.75\% per annum) calculations using a simple interest method as regulated by Center of $\mathrm{P} 2 \mathrm{H}$;

4 Annual maintenance costs is IDR2,000 per tree or IDR2,000,000 per ha (with 1000 trees ha $^{-1}$ ).

Table 4.

Average price per tree for the collateral at age five years is IDR25,000 at the beginning of loan period. Within lending period of three years, the price would be around IDR34,000-IDR46,000 per tree. Even though

Table 2 Performance of PTT-HR

\begin{tabular}{|c|c|c|c|c|c|c|}
\hline \multirow{2}{*}{ Aspect } & \multicolumn{2}{|c|}{ Wonosobo } & \multicolumn{2}{|c|}{ Blora } & \multicolumn{2}{|c|}{ Total } \\
\hline & $\mathrm{n}$ & $\%$ & $\mathrm{n}$ & $\%$ & $\mathrm{n}$ & $\%$ \\
\hline $\begin{array}{l}\text { Suitability between log price estimated by farmer } \\
\text { (borrower) and estimated by Center of } \mathrm{P} 2 \mathrm{H} \text { : }\end{array}$ & & & & & & \\
\hline Suitable & - & - & 1 & $1.7 \%$ & 1 & $1.2 \%$ \\
\hline $\begin{array}{l}\text { Not suitable (price estimates from the Center of } \mathrm{P} 2 \mathrm{H} \\
\text { is lower than the estimated price by the borrower) }\end{array}$ & 27 & $100.0 \%$ & 57 & $98.3 \%$ & 84 & $98.8 \%$ \\
\hline
\end{tabular}

Table 3 Present value of additional profits of PTT-HR for teak as collateral (IDR tree ${ }^{-1}$ )

\begin{tabular}{|c|c|c|c|c|c|c|}
\hline \multirow{2}{*}{$\begin{array}{c}\text { Tree price at the } \\
\text { end of lending } \\
\text { period } \\
(\text { IDR tree } \\
\text {-1 })\end{array}$} & \multicolumn{6}{|c|}{ Present value of additional profit (S) at interest rate (IDR tree ${ }^{-1}$ ) } \\
\hline & $5.00 \%$ & $5.75 \%$ & $6.00 \%$ & $6.50 \%$ & $7.00 \%$ & $7.50 \%$ \\
\hline 185.000 & 17.015 & 13.219 & 12.003 & 9.642 & 7.372 & 5.191 \\
\hline 200.000 & 28.768 & 24.561 & 23.212 & 20.590 & 18.067 & 15.640 \\
\hline 215.000 & 40.521 & 35.903 & 34.421 & 31.538 & 28.762 & 26.088 \\
\hline 230.000 & 52.274 & 47.245 & 45.630 & 42.486 & 39.457 & 36.536 \\
\hline 245.000 & 64.027 & 58.587 & 56.838 & 53.435 & 50.152 & 46.985 \\
\hline 260.000 & 75.780 & 69.929 & 68.047 & 64.383 & 60.846 & 57.433 \\
\hline
\end{tabular}


tree price is IDR 34,000 at the end of the loan period will giving positive present value of additional benefits, but that is not so interesting cause of little amount of additional benefits (ranging IDR65-IDR783 per tree), even in the interest rate more than $6 \%$ the farmer will receive negative additional benefits. The decision to borrow money from the $\mathrm{P} 2 \mathrm{H}$ Center will be better and secure when the price at the end of lending period is IDR 37,000 and more, even the annual interest rate raise up to $7.5 \%$ (Table 4 ).

At the beginning of loan period, average price per tree for the collateral at age 10 years is IDR50,000 (median of IDR40,000-IDR60,000). Within lending period of three years, the price would be around IDR68,000IDR140,000 per tree. Even though tree price is only IDR 68,000 at the end of the loan period, the decision to borrow money from the $\mathrm{P} 2 \mathrm{H}$ Center will be better and secure even if annual interest rate raise up to $7.5 \%$ (Table 5).

Effectiveness of PTT-HR During one year implementation of PTT-HR seems in line with the objectives of policy or it is effective according to criteria that proposed by Dye (2002), Dunn (2003), and Tron (2009). This can be shown by some indicators as follow:

1 The collateralized tree already has a selling price but is not yet mature enough to be felled.

2 Delaying to harvest is a lucrative option for farmers with a positive net present value of additional benefits $(S>0)$ at a specified interest rate required by Center of $\mathrm{P} 2 \mathrm{H}$.

3 Utilization of PTT-HR primarily for working (investment) capital to strengthen household income and livelihood (expressed by $77.6 \%$ of respondents). In the long term the use of PTT-HR funds for business capital is expected able to alleviate poverty, develop selfemployed farmers' businesses that can generate revenues, empower the people's economy, expand employment opportunities, and become a source of income for the strengthening of loan repayments.

4 PTT-HR is perceived as a new breakthrough, suited to the needs of the community (expressed by $82.4 \%$ of respondents), a lower interest rate $(5.75 \%)$ than the interest rate of other financial institutions $(15-20 \%)$, the application process is easy (expressed by $76.5 \%$ of respondents), loans given directly through the account of the borrower that make more transparent, and the loan amount in accordance with the proposed one (expressed by $96.5 \%$ of respondents).

5 The availability of other sources of revenue for repayment of the loan (expressed by $95.3 \%$ of respondents). So the concern of Bichanga \& Aseyo (2013) that mentions one of the causes of failure of micro-credit loan repayment is the lack of asset can be minimized.

However, there are still some weaknesses of the system as perceived by respondents as listed below:

1 Processing time of loan applications is still too long (100\% of respondents stated above 120 days). Clarification to the $\mathrm{P} 2 \mathrm{H}$ Center states that the delay was caused by the provision of the loan must be done prudentially, the system is not perfect yet and the number of officers are limited to verify the proposal.

2 Loan that are delivered in two or more phases reduced the chance of the farmers to use the loan for a significant needs $(96.5 \%$ of respondents wants the one-time payment).

3 There were complaints that the price estimates from the Center of $\mathrm{P} 2 \mathrm{H}$ is lower than the estimated price of the

Table 4 Present value of additional profits of PTT-HR for sengon as collateral (IDR tree ${ }^{-1}$ )

\begin{tabular}{crrrrrr}
\hline $\begin{array}{c}\text { Tree price at the end } \\
\text { of lending period } \\
\text { (IDR tree }\end{array}$ & \multicolumn{5}{c}{ Present value of additional profits (S) at interest rate } \\
\cline { 2 - 7 } & $5.00 \%$ & $5.75 \%$ & $6.00 \%$ & $6.50 \%$ & $7.00 \%$ & $7.50 \%$ \\
\hline 34.000 & 783 & 241 & 65 & $(280)$ & $(616)$ & $(944)$ \\
37.000 & 3.375 & 2.778 & 2.584 & 2.204 & 1.833 & 1.471 \\
40.000 & 5.966 & 5.315 & 5.103 & 4.687 & 4.281 & 3.886 \\
43.000 & 8.558 & 7.852 & 7.622 & 7.171 & 6.730 & 6.301 \\
46.000 & 11.149 & 10.388 & 10.141 & 9.654 & 9.179 & 8.716 \\
\hline
\end{tabular}

Table 5 Present value of additional profits of PTT-HR for teak as collateral (IDR tree ${ }^{-1}$ )

\begin{tabular}{|c|c|c|c|c|c|c|}
\hline \multirow{2}{*}{$\begin{array}{l}\text { Tree price at the } \\
\text { end of lending } \\
\text { period } \\
(\text { IDR tree }\end{array}$} & \multicolumn{6}{|c|}{ Present value at interest rate } \\
\hline & $5.00 \%$ & $5.75 \%$ & $6.00 \%$ & $6.50 \%$ & $7.00 \%$ & $7.50 \%$ \\
\hline 68.000 & 5.286 & 4.162 & 3.797 & 3.081 & 2.383 & 1.703 \\
\hline 86.000 & 20.835 & 19.383 & 18.910 & 17.983 & 17.077 & 16.192 \\
\hline 104.000 & 36.384 & 34.603 & 34.024 & 32.884 & 31.770 & 30.682 \\
\hline 122.000 & 51.933 & 49.824 & 49.137 & 47.785 & 46.463 & 45.171 \\
\hline 140.000 & 67.482 & 65.045 & 64.250 & 62.686 & 61.157 & 59.660 \\
\hline
\end{tabular}


borrower (expressed by $98.8 \%$ of respondents). This indicates that it needs to be more transparent in the pricing of trees.

4 Information provided to farmers and farmer groups often change.

5 The loan proposal was made by farmer group, but the loan was distributed to the farmers directly. This condition made farmer group administrators unhappy, because the farmer group had to bear the cost of proposal preparation without any compensation from the farmers as well as Center of $\mathrm{P} 2 \mathrm{H}$.

6 Lack of technical assistance to address the threat of pests and plant diseases as well as other factors

To overcome those weaknesses, it is required to improve the policy regarding to scaling up and scaling out of PTT-HR as follows:

1 The service of $\mathrm{P} 2 \mathrm{H}$ should be closer to the customers. It can be conducted by forming intermediary institution or develop on site level organization of $\mathrm{P} 2 \mathrm{H}$ Center. Intermediary institution or on site level organization is expected to know more about potential farmers as PTTHR customers and can provide assistances to farmers (borrowers) intensively. In other words the asymmetric information problems can be minimized.

2 Requirements and procedures need to be defined more clearly so that prospective borrowers can assess themselves properly whether they are eligible for a loan or not. For example is about eligible age of borrower candidates and document requirements. Because it was not explained at the beginning, so many candidates of borrower made preparations such as inventory and marking trees, but they did not get a loan because out of age range termed by Center of $\mathrm{P} 2 \mathrm{H}$ or because they did not able to show the original ID Card and letter of land ownership.

3 The customers want to receive loan in one stage disbursement to get flexibility in use. PTT-HR is aimed to fulfill farmer's need when they need money in urgent situation with huge amount. With PTT-HR, farmers do not have to harvest their young (or small diameter) trees to get cash for their urgent needs. In this circumstance the gradual delivery of loan disbursement is becoming less relevant. Moreover, the farmers have already handed their trees for collateral.

4 It would be better to provide the mechanism of loan repayment before due date (early repayment).

The important lesson from this study is in fact that microfinance loans (in this case is PTT-HR) be able to provide an opportunity to utilize farmer's spare time to be more productive. For example, with IDR10 million loan farmers can buy a cow and in one year they could sell the cow at IDR13 million. Such a practice has become a very long farmer's experience. Thus PTT-HR program potentially can improve welfare of participant farmer, empower rural potency, and finally accelerate rural development accordance with the role of ideal forestry microfinance as stated by Gondo (2009) who mentioned that community based sustainable forest management needs financial support and access to increase participation of local communities in forest management, provide livelihood opportunities, and alleviate the poverty.

\section{Conclusion}

Based on the evaluation parameters derived from PTT-HR objectives which include collateralized stand age, the ability to improve farmer's welfare, loan utilization, perceptions about the ease of the process and the intended use, as well as repayment ability, it seems PTT-HR policies have been implemented effectively, at least for a period of about one year implementation. According to the borrower, however, there are some weaknesses in the implementation, such as the process takes too much time, the phases of the loan disbursement that is not in accordance with the wishes and needs of farmers, the estimated price is low, information on lending requirements and procedures that are not clear, the involvement of farmer groups in the disbursement of funds, and lack of technical assistance to address the threat of failure in managing collateral trees. The research also raises further questions such as whether the 3-year lending period for short-cycle (such as sengon) and the 5-year lending period for long-cycle (such as jati) is optimal term and whether the PTT-HR program is efficient.

\section{Recommendations}

To overcome the weaknesses of the implementation of PTT-HR and to scale up as well as to scale out the program, there are some necessary corrective actions required, they are (1) to develop an organization of Center of $\mathrm{P} 2 \mathrm{H}$ at site level or alternatively creating intermediary institution to put Center of $\mathrm{P} 2 \mathrm{H}$ closer to its customers, (2) to make requirement and procedures of borrowing clearly, (3) to rearrange the stage of loan delivery, (4) to provide technical assistance through organization of Center of $\mathrm{P} 2 \mathrm{H}$ at site level as well as local forestry extension official to minimize the failure of loan repayment, (5) to provide early repayment mechanism, and (6) to scale up and scale out the service of PTT-HR because the scheme allowed farmers to employ their spare time more productively, and (7) to perform further research focusing on efficiency of the implementation of PTT-HR policy as well as to calculate optimum lending period both for short-cycle species and long-cycle species.

\section{Acknowledgements}

This study is part of research "PRO-FORMAL: Policy and regulatory options to recognize and better integrate the domestic timber sector in tropical countries" funded by CIFOR. Deep gratitude is directed to Hafid Hakim and Bayu Pranayudha who have helped in the collection of field data and information.

\section{References}

Ajit D, Rajeev CB. 2012. Micro-finance and social capital: A study of microfinance institutions in Andhra Pradesh, India. International Journal of Social Inquiry 5(1-2):67-84.

Bichanga WO, Aseyo L. 2013. Causes of loan default within microfinance institutions in Kenya. Interdisciplinary Journal of Contemporary Research in Business 


$$
\text { 4(12):316-335. }
$$

Dunn WN. 2003. Pengantar Analisis Kebijakan Publik. Translated from: Public Policy Analysis: An Introduction. Wibawa S, Asitadani D, Hadna AH, Purwanto EA, translator. Jogjakarta: Gadjah Mada University Press.

Dye TR. 2002. Understanding Public Policy. USA: PrenticeHall.

Ejigu L. 2009. Performance analysis of a sample microfinance institutions of Ethiopia. International NGO Journal 4(5):287-298.

Elliott J. 2005. Using Narrative in Social Research: Qualitative and Quantitative Approaches. London: SAGE Publications. https://doi.org/10.4135/9780857020246.

Gondo PC. 2009. The role of micro-financing in sustainable forest management. In: Proceeding XIII World Forestry Congres; Buenos Aires, 18-23 October 2009. Pp 1-12.

Hardjanto. 2001. Kontribusi hutan rakyat terhadap pendapatan rumah tangga di Sub DAS Cimanuk Hulu. Jurnal Manajemen Hutan Tropika 7(2):47-61.

Irawan P. 2007. Penelitian Kualitatif dan Kuantitatif untuk Ilmu-ilmu Sosial. Jakarta: DIA Fisip UI Press.

Khandker SR, Khalily B, Khan Z. 1995. Grameen Bank: Performance and Sustainability. World Discussion Paper 306. Washington DC: The World Bank.

Nugroho B. 2010. Institutional development for community forest revolving fund. Jurnal Manajemen Hutan Tropika 16(3):118-125.

Nugroho B. 2011. Comparative analysis of credit schemes for community-based forest plantation in Indonesia. Jurnal Manajemen Hutan Tropika 17(2):79-88.

Nugroho B, Tiryana T. 2013. Implications of the private property right to the community forest businesses formalization through the certification policy. Jurnal Manajemen Hutan Tropika 19(3):178-186. https://doi.org/ 10.7226/jtfm.19.3.178.

Ondoro CO, Omena D. 2012. Effect of microfinance services on the financial empowerment of youth in Migori County, Kenya. Business and Management Review 2(3):22-35.

Onoja AO, Agumagu AC. 2009. Econometric modeling of the effects of economic policies on food output in Nigeria under Obasanjo's administration. Journal of Sustainable Development in Africa 11(1):98-112.

Prihadi N. 2010. Kelembagaan kemitraan industri pengolahan kayu bersama rakyat dalam rangka pembangunan hutan di Pulau Jawa [dissertation]. Bogor: Bogor Agricultural
University.

Qureshi MI, Saleem MA, Shah M, Abbas Z, Qasuria AW, Saadat UR. 2012. Ensuring the role and impact: Reaching the poorest while alleviating the poverty by micro finance in Dera Ismail Khan Khyber Pakhtunkhwa Pakistan. Interdisciplinary Journal of Contemporary Research in Business 3(11):646-655.

Rauf SA, Mahmood T. 2009. Growth and performance of microfinance in Pakistan. Pakistan Economic and Social Review 47(1):99-122.

Ridwan. 2009. Pengantar Statistika Sosial. Bandung: Alfabeta.

Singh S. 2012. Micro finance: A conceptual analysis. Asian Journal of Research in Banking and Finance 2(12): 44-57.

Tee J, Scarpa R, Marsh D, Guthrie G. 2010. A binomial tree approach to valuing fixed rotation forests and flexible rotation forests under a mean reverting timber price process. http: ageconsearch.umn.edu/bitstream/ 96836/2/2010_11_binomial tree.pdf. [21 November 2013].

Trón Z. 2009. Evaluation methods of European regional policy and reasons for different outcomes. The Romanian Economic Journal Year XII 32(2):149-185.

Usman S, Suharyo WI, Sulaksono B, Mawardi MS, Toyamah N, Akhmadi. 2004. Lessons Learned from Microfinance Services in East Nusa Tenggara. Jakarta: SMERU Research Institute.

Varone F, Benoit R, Axel M. 2006. A new methode for policy evaluation? Longstanding challenges and the possibilities of qualitative comparative analysis (QCA). In: Rihoux B, Grimm H, editor. Innovative Comparative Methods for Policy Analysis: Beyond the Quantitative-Qualitative Divide. New York: Springer Science Business Media Inc. Pp213-236. https://doi.org/10.1007/0-387-28829-5_10.

Wijono WW. 2005. Pemberdayaan lembaga keuangan mikro sebagai salah satu pilar sistem keuangan nasional: upaya konkrit memutus mata rantai kemiskinan. Jurnal Ekonomi Rakyat Edisi Khusus November 2005:86-100.

Yunus M. 1981. Credit for self employment: A fundamental human right. Grameen Bank. Dhaka. http://www.worldfooddayusa.org/Object.File/Master/17/ 331/Yunuspaper.pdf. [2 November 2010].

Yunus M. 2007. Bank Kaum Miskin: Kisah Yunus dan Grameen Bank Memerangi Kemiskinan. Nasution I, translator. Translated from: Banker to the Poor: Microlending and the Battle Against World Poverty. Depok: Marjin Kiri. 